Wrocławskie Studia Wschodnie

23 (2019)

Wydawnictwo Uniwersytetu Wrocławskiego

DOI: $10.19195 / 1429-4168.23 .6$

NATALIA MARIA Kotrys

ORCID: 0000-0002-5039-6977

Uniwersytet Wrocławski

\title{
Województwo poleskie w polskich reportażach z okresu dwudziestolecia międzywojennego - wybrane aspekty*
}

Niniejszy tekst jest poświęcony wizerunkowi województwa poleskiego $\mathrm{w}$ polskich reportażach $\mathrm{z}$ okresu dwudziestolecia międzywojennego. Scharakteryzowanie tego malowniczego, otoczonego przez łąki i bagna terenu z niezwykle złożoną sytuacją narodowościową, społeczną oraz polityczną, nie było najłatwiejsze. Dzięki analizie wybranych reportaży Polesie zostanie przedstawione $\mathrm{z}$ punktu widzenia autorów tekstów z pogranicza publicystyki oraz literatury faktu. Na wstępie należy zaznaczyć, że reportaż jest klasyfikowany jako gatunek prozy publicystycznej; jest to żywy opis zdarzeń oraz faktów znanych autorowi dzięki bezpośredniej obserwacji ${ }^{1}$. Z punktu widzenia historyka reportaż jest źródłem trudnym, lecz ciekawym.

Dziennikarzy i podróżników z czasów dwudziestolecia międzywojennego interesowały przede wszystkim tajemnice obrzeży poznawanych krajów ${ }^{2}$. Starali się zrozumieć miejsca zamieszkiwane przez ludzi, których dotknęła bieda, niedostatek. Należy w związku z tym zadać sobie pytanie: w jaki sposób został przedstawiony obraz Polesia przez reportażystów, publicystów w dwudziestoleciu międzywojennym oraz co było tak interesującego w omawianym regionie, że wielu decydowało się na badanie tego miejsca.

* Niniejszy tekst zajął trzecie miejsce w „Międzynarodowym białorusko-polskim konkursie studenckich prac naukowych $\mathrm{z}$ dziedziny historii z okazji 25. rocznicy nawiązania stosunków dyplomatycznych pomiędzy Republiką Białoruś i Rzeczpospolitą Polską”, który odbył się w dniach 27-29 września 2017 roku w Mińsku.

1 Stownik języka polskiego, red. M. Szymczak, t. 3, Warszawa 1979, s. 47.

${ }^{2}$ U. Gleńsk, Historia słabych. Reportaż i życie w dwudziestoleciu (1918-1939), Kraków 2014, s. 13.

Wrocławskie Studia Wschodnie 23, 2019

(C) for this edition by CNS 
Przy analizie problematyki Polesia nie mogło zabraknąć reportaży oraz tekstów takich publicystów, jak Józef Mackiewicz, Stanisław Tołpa, Ksawery Pruszyński, Antoni Ferdynand Ossendowski czy Wanda Wasilewska. Autorka dokonała wyboru nieprzypadkowo, gdyż ich utwory doskonale oddają charakter województwa poleskiego.

Józef Mackiewicz miał opinię antykomunisty i kontrrewolucjonisty, należy jednak podkreślić, że nigdy nie utożsamiał się z konkretną opcją polityczną ${ }^{3}$. Jego zbiór reportaży wybranych spośród tekstów publikowanych w wileńskim „Słowie” został wydany w roku 1938 jako Bunt rojstów. Dotyczyły one wschodnich terenów przedwojennej Polski. Autor w ramach swojej działalności z okresu dwudziestolecia międzywojennego zasłynął z obrony ludności kresowej ${ }^{4}$.

Z kolei Stanisław Tołpa, do którego publikacji również nawiązano w niniejszym tekście, był twórcą szkoły torfoznawczej oraz znanym badaczem największych kompleksów torfowiskowych w Polsce. Jednocześnie piastował funkcję pierwszego rektora Wyższej Szkoły Rolniczej we Wrocławiu; jest autorem wielu publikacji z florystyki i ekologii torfowisk ${ }^{5}$.

Kolejny autor, Ksawery Pruszyński, należał do środowiska młodych konserwatystów, a jego działalność również skupiała się wokół środowiska akademickiego ${ }^{6}$. Publikował w krakowskim „Czasie” oraz wileńskich „Słowie” i „Wiadomościach Literackich”. W latach trzydziestych XX wieku odbył podróż po Polsce, która zaowocowała wydaniem w 1936 roku (między majem a październikiem) w liberalnych „Wiadomościach Literackich” cyklu reportaży zatytułowanych Podróż po Polsce. Pod tym samym tytułem w 1937 roku ukazała się książa Pruszyńskiego. Znalazły się w niej w całości reportaże opublikowane w „Wiadomościach Literackich” oraz dwa dodatkowe, mianowicie Michat Kleofas oraz Wtaściciel galerii portretów. Teksty te zamieszczono w 1936 roku w wileńskim czasopiśmie „Czas”. W reportażach autora pojawiły się informacje dotyczące między innymi Lwowa po rozruchach w 1936 roku $^{7}$, rozwarstwienia proletariatu łódzkiego ${ }^{8}$, ślubowania młodzieży akademickiej na Jasnej Górze ${ }^{9}$, pogromu w Przytyku ${ }^{10}$, konfliktu narodowościowe-

3 D. Rohnka, A ja przeciwnie... Szkice o Józefie Mackiewiczu, Londyn 1997, s. 12.

${ }^{4}$ Ibidem, s. 7.

${ }^{5}$ Wroctawskie środowisko akademickie. Twórcy i ich uczniowie 1945-2005, red. A. Chmielewski, Wrocław 2007, s. 252.

${ }^{6}$ R. Kaczmarek, Historia Polski 1914-1989, Warszawa 2010, s. 257.

${ }^{7}$ K. Pruszyński, Wśród szkła i plakatów, „Wiadomości Literackie” (dalej: WL) 1936, nr 24, s. 2.

${ }^{8}$ K. Pruszyński, Żótci ludzie z Łodzi, WL 1936, nr 25, s. 1.

${ }^{9}$ K. Pruszyński, Ślubowanie, WL 1936, nr 26, s. 2.

10 K. Pruszyński, Przytyk i stragan, WL 1936, nr 30, s. 1.

Wrocławskie Studia Wschodnie 23, 2019

(C) for this edition by CNS 
go na Wołyniu ${ }^{11}$, budowy zapory w Porąbce i Rożnowie ${ }^{12}$ czy cywilizacyjnej roli fabryki dykty na Polesiu ${ }^{13}$.

Antoni Ferdynand Ossendowski był dziennikarzem, podróżnikiem o antykomunistycznych poglądach. Opublikował wiele powieści, przede wszystkim o charakterze podróżniczym.

Kolejną postacią, do której publikacji autorka odwołuje się w artykule, jest Wanda Wasilewska. Była ona początkowo działaczką PPS, a następnie zagorzałą komunistką. Współpracowała z wieloma lewicowymi czasopismami, na łamach których propagowała poglądy komunistyczne. W niniejszym tekście przytoczono również fragmenty opracowanego przez nią przewodnika po Polesiu. Zabiegu tego dokonano w celu lepszego przedstawienia opisywanego terenu.

\section{Charakterystyka Polesia}

Polesie jest krainą geograficzno-historyczną leżącą na terenie dzisiejszej Białorusi, Ukrainy, Polski oraz Rosji. Jak pisał Ossendowski,

Polesie więc wbija się klinem pomiędzy jeziorną krainę Litwy i wyżynę Białoruską od północy; od południa — graniczy z płytą podolską i wyżyną Wołynia, na wschodzie zaś, z rzadka przekraczając Dniepr — dociera do koryta jego — od Mohilewa niemal aż po daleki Kijów ${ }^{14}$.

Polesie, niezwykle bogate w piękno natury, pozbawione było jednak dogodnych warunków do życia dla jego mieszkańców. Historia omawianych ziem od zawsze charakteryzowała się złożoną sytuacją ekonomiczną, społeczną oraz narodowościową. W okresie dwudziestolecia międzywojennego opisywane w tekście województwo zajmowało zachodnią część Polesia geograficznego, natomiast po II wojnie światowej w wyniku zmiany granic w części państwa polskiego znalazł się jedynie skrawek dawnego województwa poleskiego. W latach 1918-1939 w województwie poleskim występowała bardzo niska gęstość zaludnienia - w latach trzydziestych XX wieku $1 \mathrm{~km}^{2}$ zamieszkiwały jedynie 34 osoby $^{15}$. Teren był trudno dostępny, jako że Polesie należało do krain bagiennych, z dziko płynącymi wodami, które często utrudniały komunikację. Infrastruktura komunikacyjna $\mathrm{w}$ porównaniu $\mathrm{z}$ innymi regionami II Rzeczypospolitej była czterokrotnie rzadsza ${ }^{16}$.

11 K. Pruszyński, Prawo do Wotynia, WL 1936, nr 43, s. 3.

12 K. Pruszyński, $O$ wóz i o konia, WL 1936, nr 41, s. 4.

13 K. Pruszyński, Kietkowanie na bagnie, WL 1936, nr 35, s. 2.

14 A.F. Ossendowski, Polesie, Poznań 1935, s. 10.

15 P. Cichoracki, Województwo poleskie 1921-1939. Z dziejów politycznych, Łomianki 2014, s. 15.

16 P. Cichoracki, Polesie nieidylliczne, Łomianki 2007, s. 13.

Wrocławskie Studia Wschodnie 23, 2019

(C) for this edition by CNS 
Województwo poleskie było swoistym tyglem narodowościowym, kulturowym oraz politycznym — obok siebie mieszkali tutaj przedstawiciele kilku religii, narodowości, przekonań politycznych. Według spisu powszechnego z 1921 roku ludność województwa poleskiego stanowili między innymi: Białorusini (42,6\%), Polacy (24,3\%), Ukraińcy (17,7\%), Żydzi (10,4\%), „tutejsi” $(4,4 \%)$ i Rosjanie $(0,5 \%)^{17}$. Jeśli natomiast chodzi o wyznania, to według spisu z roku 1931 układają się one następująco: prawosławie $72,9 \%$, katolicyzm - 15,0\%, judaizm - 8,9\%. Województwo poleskie zgodnie ze spisem ludności z 1931 roku liczyło 1134538 mieszkańców, natomiast miasta, takie jak Brześć, Pińsk, Dawidgródek, Kobryń i Prużana, zamieszkiwała piąta część ogółu ludności ${ }^{18}$. Resztę, czyli 80\%, stanowiła ludność rolnicza, wiejska.

Nazwa „Polesie” przez długi czas była powodem sporów. Jak bowiem pisał w swoim reportażu Antoni F. Ossendowski, ,Jedni twierdzą, że oznacza ona kraj lasów, drudzy — połać bagienno-leśną, za pasmem prawdziwych borów się rozcierającą"19. Nazwa prawdopodobnie wzięła się od charakterystyki regionu, czyli terenu zalesionego z dużą ilością bagien.

Polesie zamieszkiwali Poleszucy, posługujący się językiem będącym mieszaniną białoruskiego, rosyjskiego, ukraińskiego oraz polskiego. Określali się oni mianem „tutejszych”, które było samookreśleniem przynależności kulturowo-etnicznej. Należy jednak podkreślić, że „tutejsi” byli częścią grup narodowości białoruskiej bądź ukraińskiej ${ }^{20}$.

\section{Krajobraz}

Krajobraz województwa poleskiego to w $56 \%$ bagna oraz podmokłe tereny ${ }^{21}$. Cechą charakterystyczną regionu były moczary, łąki, lasy, które tworzyły trudny, niedostępny dla ludzi teren. Trafnie ukazują to słowa Józefa Mackiewicza:

Człowiek nie znający Polesia wyobraża sobie jego słynne bezdroża — trochę ,po naszemu", po wileńsku t. zn. bardzo kiepskie drogi, lubo nawet niemożliwe do przejechania. $\mathrm{Na}$ Polesiu bezdroże jest dosłowne. W niektórych miejscowościach dróg kołowych nie ma wcale a wcale ${ }^{22}$.

W niektórych reportażach $\mathrm{z}$ okresu dwudziestolecia międzywojennego można znaleźć wiele fragmentów, w których zwracano szczególną uwagę na charakter krajobrazu występującego na omawianym terenie. Pierwszym

17 P. Cichoracki, Województwo poleskie..., s. 21.

18 M. Marczak, Przewodnik po Polesiu, Brześć nad Bugiem 1935, s. 23.

19 A.F. Ossendowski, op. cit., s. 8-9.

20 P. Cichoracki, Województwo poleskie..., s. 25.

21 W. Śleszyński, Województwa kresowe II RP. Województwo poleskie, Kraków 2014, s. 35.

22 J. Mackiewicz, Bunt rojstów, Warszawa 1990, s. 113.

Wrocławskie Studia Wschodnie 23, 2019

(C) for this edition by CNS 
autorem, do którego publikacji warto w tym miejscu nawiązać, jest Józef Mackiewicz. W książce Bunt rojstów prócz opisów Wileńszczyzny oraz Ukrainy znajduje się bowiem cykl reportaży o Polesiu. W tekście zatytułowanym Największy pożar w Europie Mackiewicz opisał pożar, który dotarł do Pińska. Warto zaznaczyć, że tego rodzaju zdarzenia często miały miejsce na terenie Polesia. Były to w szczególności podpalenia łąk oraz bagien. W omawianym tekście przytaczane są wspomnienia świadków wydarzeń, którzy wspominali, że „ogień rozpowszechniał się z taką szybkością, że uniemożliwiał jakikolwiek ratunek"23. Próby gaszenia pożaru były szczególnie utrudnione przez teren, na którym doszło do zdarzenia. Jak pisał Mackiewicz:

Polesie jest w stosunku odwrotnym do innych puszcz naszych. Tamte stanowią dziś już tylko wyspę wśród terenu cywilizacji rolniczej. Tu jest przeciwnie: teren — to puszcza, a cywilizacja trzyma się tylko na pojedynczych wyspach ${ }^{24}$.

Ponadto trudno było ustalić, kto odpowiadał za podpalenia. Wszystko to sprawiało, że pożary stanowiły niesamowite zagrożenie dla dorobku ludności zamieszkującej opisywane tereny. Pożar w głównej mierze oznaczał straty gospodarcze.

W tym samym reportażu, oprócz relacji z pożaru, znajduje się opis bezdroży Polesia ${ }^{25}$. Jak już wspomniano, komunikacja na omawianym terenie była trudna, ograniczona, a z powodu braku dróg kołowych transport odbywał się w dużym stopniu szlakami wodnymi bądź z wykorzystaniem sani. Już na samym początku Mackiewicz zauważył jeden z największych problemów Kresów Wschodnich, w szczególności Polesia, do którego często później nawiązywał - drogi bite na terenie województwa poleskiego stanowiły mniej niż $10 \%$ długości wszystkich dróg w tym regionie ${ }^{26}$. Pokazuje to, jak trudna była komunikacja na tym terenie oraz że nie tylko ograniczało to codzienną komunikację, lecz także bezpośrednio wpływało na rozwój gospodarski w województwie. W zbiorze reportaży Mackiewicza znajduje się również tekst opisujący podróż po Prypeci, którą dziennikarz był zachwycony.

Bunt rojstów to opis poleskich krajobrazów, puszczy, bagien, które robią wrażenie nie tylko na autorze reportaży, ale i innych przybyłych na tereny kresów wschodnich Rzeczypospolitej. Mackiewicz zarysował obraz Polesia niedocenionego, zapomnianego często pomijanego przez społeczeństwo II RP. Realizm publicysty sprawia, że idealistyczna wizja omawianego regionu mija się z prawdą. Nie bał się on w ironiczny sposób krytykować polskiej administracji i ignoranckiego traktowania ziem kresowych, przede wszystkim Polesia. Można sądzić, że opis stworzony przez tego reportażystę był jednym

23 Ibidem, s. 119.

24 Ibidem, s. 120.

25 Ibidem, s. 115.

${ }^{26}$ P. Cichoracki, Polesie nieidylliczne..., s. 13.

Wrocławskie Studia Wschodnie 23, 2019

(C) for this edition by CNS 
ze szczególnie realistycznych i najlepiej oddających wizerunek województwa poleskiego w okresie dwudziestolecia międzywojennego.

$\mathrm{Z}$ podróży po Polesiu wspomnienia spisał również Stanisław Tołpa. W publikacji Śladami łosia. Z wędrówek po Polesiu opisywał między innymi krajobraz Polesia, pełen bagien oraz dzikich nieodkrytych miejsc ${ }^{27}$. Autor znalazł się na terenie omawianego województwa w związku z prowadzonymi przez niego badaniami naukowymi nad bagnami oraz torfowiskami. Złe warunki drogowe często jednak nie pozwalały naukowcom podróżować samochodem po Polesiu; w takich sytuacjach dalszą podróż odbywano pieszo $^{28}$. Jego opisy przyrody były szczególnie dokładne, w dodatku autor oddawał krajobraz województwa poleskiego z punktu widzenia naukowca i przyrodnika.

Krajobraz województwa poleskiego wyłania się również w reportażach Ksawerego Pruszyńskiego. W tekście Michat Kleofas swoją uwagę Pruszyński poświęcił Polesiu, a konkretnie Kanałowi Ogińskiemu, który zrobił na nim niesamowite wrażenie. Jak pisał:

Komuś, co Polesie nie zjeździł, nie wlókł się godzinami po piachu, nie jechał smrodliwą kolejką, nie widział tej nędzy, biedy, biedy cherlawych Żydów, brudnych dzieciaków tabunami, o jakich w centralnej Polsce nie ma się pojęcia, nie zrozumie, jakie wrażenie robi ten prosty kanat $^{29}$.

Powstał on w epoce saskiej, w okresie trudnym dla Rzeczypospolitej; był jednym z najsłynniejszych kanałów dawnego państwa polskiego. Pruszyński doceniał niesamowitą wartość opisywanej drogi wodnej dla gospodarki Polesia — dzięki niemu został bowiem wytyczony kolejny szlak transportowy, co usprawniłoby komunikację. Na chwilę obecną kanał znajduje się w obwodzie brzeskim na Białorusi, a od 2006 roku prowadzone są prace nad jego odbudową.

Z kolei Antoni F. Ossendowski w publikacji Polesie, wydanej w 1935 roku, w niezwykle nostalgiczny i przejmujący sposób opisał omawiany tu region. Jego zdaniem na tym terenie w naturze nic nie zmienia się od wieków — są to wciąż te same lasy, bagna, jeziora, te same rzeki z największą Prypecią. Fauna i flora Polesia zachwycała Ossendowskiego. Analizując opis dziennikarza, odczuwa się klimat idylli, jaką było Polesie. Wszystko z sobą współgrało: rośliny, zwierzęta oraz pogoda, a Poleszucy — mieszkańcy Polesia — za swój „żywioł" uważali błoto, wodę oraz lasy. Z zapisków Ossendowskiego wyłania się obraz ludzi potrafiących radzić sobie w wyjątkowo trudnych warunkach

27 S. Tołpa, Śladami łosia. Z wędrówek po Polesiu, Lwów 1936.

28 Ibidem, s. 71.

${ }^{29}$ K. Pruszyński, Michat Kleofas, [w:] idem, Podróż po Polsce, Warszawa 2000, s. 84.

Wrocławskie Studia Wschodnie 23, 2019

(C) for this edition by $\mathrm{CNS}$ 
życiowych, a ich doświadczenie łowieckie oraz zwyczaje sprawiały, że byli oni w stanie zapewnić wyżywienie całej rodzinie.

Ossendowski szczególną rolę przypisywał Prypeci - miejscu, w którym można było spotkać niezliczone ilości kaczek, gęsi, czajek, bekasów, dubeltów czy też batalionów. Wśród wód poleskich swoje domy miały również czarne bociany oraz szare czaple. To właśnie przy Prypeci oraz jeziorach i strumieniach mają miejsce polowania na kaczki.

Nieco uwagi autor poświęcił także warunkom, w jakich żyli Poleszucy. Jak pisał:

Wnętrze chaty jest prawie wszędzie jednakowe. Ciekawem zjawiskiem jest stary pułap poleskiej chaty — nie poziomy, lecz łukowaty, jak wieko trumny. Dookoła izby ciągną się ławy do siedzenia i spania. W kącie, zwanym ,ppokuciem”, naprzeciwko pieca, stoi stół $1^{30}$.

Autor zauważył również, że wśród ludności zamieszkującej Polesie zaczęły zanikać tradycyjne stroje, a przyjmowały się współczesne ubrania, czyli sukienki, garnitury czy pantofle na obcasach. Należy jednak wspomnieć, że proces zmiany strojów zachodził dosyć powoli. Ossendowski w wyjątkowo barwny sposób przedstawił też wierzenia, zwyczaje, zachowanie ludności Polesia. Pokazał, jak można mieć bogate i ciekawe życie mimo niedostatku, jaki panował na opisywanym terenie.

Dzięki publikacji Ossendowskiego można poczuć się oczarowanym Polesiem, jego naturą, klimatem oraz ludźmi. Po publikacji książki na jej autora spadła jednakże fala krytyki. Zarzucano mu przekoloryzowanie Polesia oraz mijanie się z prawdą. Trudno określić, czy krytyka była słuszna, czy też nie.

Należy jednak pamiętać, że oryginalność Polesia polegała na jego izolacji, która doprowadziła do zachowania odrębności regionu ${ }^{31}$. Bogactwo krainy pod względem krajobrazu sprawiało, że tworzył się obraz miejsca niezwykłego, nieodkrytego. W każdym ze zbiorów reportaży w mniejszy bądź większy sposób opisywano zatem krajobraz naturalny Polesia, który był nieodzowną częścią tego regionu.

\section{Sytuacja społeczna}

Problem ludności zamieszkującej województwo poleskie w okresie II Rzeczypospolitej należał do kwestii szczególnie skomplikowanych. Różnorodność pod względem narodowościowym, kulturowym oraz religijnym była bowiem odczuwalna $\mathrm{w}$ wielu aspektach życia mieszkańców Polesia. Jak już wspomniano, ludność omawianego terenu w 1921 roku składała się w głównej mierze z Białorusinów, Ukraińców i Polaków. Według kryteriów językowych szczególnie istotną grupą byli „tutejsi”, ponieważ grupa ta nie była w stanie określić własnej

30 A.F. Ossendowski, op. cit., s. 119.

31 J. Obrębski, Polesie. Studia etnosocjologiczne, Warszawa 2007, s. 450.

Wrocławskie Studia Wschodnie 23, 2019

(C) for this edition by CNS 
narodowości oraz języka. Należy również podkreślić, że poziom analfabetyzmu $\mathrm{w}$ województwie poleskim był jednym $\mathrm{z}$ najwyższych $\mathrm{w}$ porównaniu $\mathrm{z}$ innymi regionami państwa ${ }^{32}$. Życie kulturowe opierało się tu przede wszystkim na ludowych tradycjach, które były w tym rejonie niezmiernie cenione. Społeczeństwo było jednak nieufne wobec innych narodowości, co wiązało się $\mathrm{z}$ aspektami historycznymi tego regionu, za co odpowiedzialne miały być rządy rosyjskie ${ }^{33}$.

Opisując Polesie na podstawie wybranych reportaży, warto zwrócić uwagę na jeden z tekstów Wandy Wasilewskiej, opublikowany w czasopiśmie „Wiadomości Literackie”. W reportażu tym autorka skupiła się bowiem W głównej mierze na mniejszości żydowskiej. W Szukam antysemityzmu Wasilewska ukazała województwo poleskie, w którym życie Żydów było sielankowe i bezproblemowe ${ }^{34}$. W jej odczuciu stosunki między ludnością wyznania mojżeszowego a katolickiego czy też prawosławnego należało uznać za poprawne. Jak pisała, dzieci katolickie oraz żydowskie bawiły się z sobą, a ludzie obu wyznań wykonywali te same obowiązki i nie różnili się niczym prócz wyznania:

Tu w Szczytyniu Żyd jedzie w pole orać, Żydówki pielą w ogrodzie, żną sierpem trawę dla krów, i niemal nie odróżniają się od chłopek, z sąsiednich chałup. I chłop nie robi, nie dostrzega żadnej różnicy ${ }^{35}$.

Jej wizja kwestii braku antysemityzmu była wręcz idealistyczna — Wasilewska podważała funkcjonowanie tego zjawiska w opinii publicznej. Spojrzenie publicystki na temat kwestii żydowskiej w dwudziestoleciu międzywojennym mogło mieć ścisły związek z jej poglądami oraz programem politycznym Polskiej Partii Socjalistycznej. Przedstawiany przez nią wizerunek społeczeństwa ze szczególnym uwzględnieniem ludności żydowskiej może w związku z tym wydawać się propagandowy, przejaskrawiony. Tak pozytywny obraz wyznawców judaizmu pojawia się jedynie $\mathrm{w}$ nielicznych reportażach czy publikacjach z czasów II Rzeczypospolitej.

Pruszyński w swoim reportażu Kiełkowanie na bagnie ukazał Żydów, którzy byli źródłem nowinek ze świata. To u nich zaopatrywano się w różne produkty i to z nimi dyskutowano ${ }^{36}$. Ich sytuacja w II Rzeczypospolitej, a także na terenie województwa poleskiego była jednak skomplikowana. Społeczność żydowska odgrywała istotną rolę w życiu społecznym oraz gospodarczym. Szczególnie wysoki odsetek tej ludności pracował w wolnych zawodach,

32 M. Kitajczuk, Burzliwe dzieje Polesia, Wrocław 2002, s. 98.

33 P. Cichoracki, ,Palâšuk” — ab'ekt cyvilizacyjnaj misì̀ ì pakryŭdžany suajčynnčk: pravaslaŭnyâ vâskovy âžyhary Paleska gavaâvodstva ŭ pol'skaj papulârnaj litaratury mižvaenna gaperyâdy, „Arche Pačatak” 2014, nr 7-8, s. 78.

34 W. Wasilewska, Szukam antysemityzmu, WL 1937, nr 40, s. 3.

35 Ibidem.

${ }^{36}$ K. Pruszyński, Kiełkowanie na bagnie...

Wrocławskie Studia Wschodnie 23, 2019

(C) for this edition by CNS 
przez co byli atakowani przez prasę ${ }^{37}$. Ludność żydowska trudniła się przede wszystkim handlem, rzemiosłem czy też prowadzeniem karczm. Ich wizerunkowi towarzyszyła opinia wyzyskiwacza, spekulanta czy oszusta. Ich opis w tekście Pruszyńskiego był wprost przeciwny do tego, co przedstawiała Wasilewska. Należy również zaznaczyć, że ludność ta była szczególnie często o wiele lepiej wykształcona w porównaniu z innymi narodowościami II RP. Należy w tym miejscu podkreślić, że większość mieszkającej na terenie województwa poleskiego inteligencji stanowili Żydzi ${ }^{38}$.

Niekorzystny wizerunek judaistycznego społeczeństwa wzmocniły wydarzenia mające miejsce w Brześciu w maju 1937 roku. W czasie służby policyjnej został wówczas zamordowany śledczy Stefan Kędziora. Sprawcą zdarzenia miał okazać się jeden z Żydów mieszkających w Brześciu. Polskie społeczeństwo $\mathrm{w}$ akcie zemsty zaczęło $\mathrm{w}$ związku z tym demolować sklepy oraz domy prywatne żydów. Jak zauważył Mackiewicz, pomiędzy Polakami a Żydami panowała niechęć oraz nienawiść ${ }^{39}$. Wydarzenia w Brześciu jeszcze pogłębiły różnice między tymi narodami.

W kolejnym reportażu — Przez błotna pustynię wiedzie droga do raju Mackiewicz ukazał Polesie jako obszar nieodkryty, gdzie znajduje się wieś, do której nikt nie mógł dotrzeć — nawet urzędnicy państwowi. Mowa tutaj o wsi Mitrycze w powiecie kossowskim, gminie Piaseckie. Legenda głosiła, że wieś ta była odcięta od świata, a ludzie ją zamieszkujący żyli w warunkach jeszcze przedhistorycznych, nie wiedząc na przykład o I wojnie światowej, uciekając przed obcymi, i co najważniejsze — do tej pory nie dotarli tam poborcy podatkowi ${ }^{40}$. Legendarna wieś stanowiła dla ludzi „raj”, który omijała największa „tragedia”, czyli wspomniani poborcy. Prawda okazała się jednak zupełnie inna. Mitrycze zamieszkiwane były przez jedną, skrajnie biedną rodzinę, a do wsi wiodła niezwykle trudna droga. Dla ogółu społeczeństwa ta nieucywilizowana wieś była jednak rajem, w którym ludzie odnajdywali spokój, co niestety nie było zgodne z rzeczywistością. Wieś była praktycznie opuszczona, a legenda o tym, że nikt tam nie dotarł, była nieprawdziwa. W dodatku wioska została zrównana z ziemią przez Niemców podczas I wojny światowej. Co ważne, Mackiewicz w tym reportażu ukazał naiwność ludzi oraz obraz współczesnej Polski: „legenda o raju na ziemi, o raju wśród błota, bo przecież nie może przekroczyć urzędnik polski”" ${ }^{1}$.

Trzeba nadmienić, że rdzennymi Poleszukami byli w główniej mierze wieśniacy. Działalność oświatowa w okresie II Rzeczypospolitej między innymi

${ }^{37}$ R. Kaczmarek, op. cit., s. 305.

38 K. Pruszyński, Kiełkowanie na bagnie...

39 J. Mackiewicz, Okna zatkane szmatami, Londyn 2002, s. 147.

40 J. Mackiewicz, Bunt rojstów..., s. 189.

${ }^{41}$ Ibidem, s. 207.

Wrocławskie Studia Wschodnie 23, 2019

(C) for this edition by CNS 
na terenie województwa poleskiego wpłynęła na edukację omawianego regionu poprzez budowę szkół i świetlic, sprowadzano także polskich nauczycieli. Polityka szkolna w tym rejonie była jednocześnie polityką narodowościową, która miała na celu zasymilować ludność województwa w kulturze i rozszerzyć tutaj wpływ Polski ${ }^{42}$. Mackiewicz w jednym ze swoich reportaży, zatytułowanym Najcudowniejsza i najgłodniejsza wiosna, zwraca jednak uwagę, że pomimo rządowych starań do tutejszych szkół uczęszcza wyjątkowo mała liczba dzieci ${ }^{43}$. Ponadto są one niedożywione i chodzą w łachmanach. Pokazuje to po raz kolejny, w jak niezwykle złym stanie była sytuacja społeczna w omawianym województwie.

\section{Sytuacja gospodarcza, ekonomiczna}

Polesie w wyniku działań I wojny światowej zostało w znacznym stopniu zniszczone. Mimo starań polityka II RP mająca na celu pomoc gospodarczą województwu poleskiemu nie została do końca zrealizowana. Starano się poprawiać wydajność upraw, organizowano meliorację bagien. W województwie poleskim przeważały jednak małe gospodarstwa rolne ${ }^{44}$ — był to kolejny czynnik niesprzyjający wysokiemu poziomowi oraz wydajności gospodarczej. Warto również wspomnieć, że po zakończeniu I wojny światowej, w momencie gdy ustalono nowe granice województwa poleskiego, starano się zachęcić ludność polską do przenoszenia się na Polesie poprzez akcje propagujące osadnictwo na tamtym terenie ${ }^{45}$. Między innymi z powodu Wielkiego Kryzysu mającego miejsce w drugiej połowie lat dwudziestych XX wieku nie udało się jednak osiągnąć wzrostu liczby ludności. W 1937 roku na łamach czasopisma „Słowo" Mackiewicz informował o zwróceniu przez władze uwagi na rozwój robót publicznych na terenie województwa. Na te cele przeznaczono 25062500 zl, z czego 8468000 zostało wydane na budowę dróg bitych, wodnych oraz melioracji ${ }^{46}$ — było to jednak zdecydowanie za mało, zważywszy na potrzeby regionu.

Do kwestii rozwoju gospodarki rolnej, przedsiębiorstw, fabryk na terenie województwa poleskiego nawiązywał również Pruszyński. W reportażu dotyczącym szczególnie interesującej sprawy, mianowicie zatrudnienia ludności na terenie Polesia w jednej z fabryk, autor ten opisał zakład obróbki drewna w Mikaszewiczach, gdzie zatrudnienie znalazła ludność pochodząca z Polesia, byłej Kongresówki, Śląska i Poznańskiego. Dziennikarz zarysował

42 W. Śleszyński, op. cit., s. 192.

43 J. Mackiewicz, Bunt rojstów..., s. 130.

44 W. Śleszyński, op. cit., s. 132.

45 W. Śleszyński, Świat pogranicza. Stosunki społeczno-polityczne na pograniczu polskolitewsko-białoruskim w XX i XXI wieku, Białystok 2009, s. 108.

46 J. Mackiewicz, Okna zatkane szmatami..., s. 125.

Wrocławskie Studia Wschodnie 23, 2019

(C) for this edition by CNS 
jednocześnie proces zagospodarowania terenów, które do tej pory były zapomniane. Jak pisał:

W puszczę wdarł się naraz przemysł, w społeczeństwo leśnych dziadków, żyjących z myślistwa, tłukących sobie kaszę w stępach, mielących ziarno w żarnach domowych, tkających sobie odzież i krzeszących ogień z hubki, stanął - robotnik ${ }^{47}$.

Mieszkania należące do robotników były czyste, często doglądane przez opiekę społeczną. Pod nadzorem pielęgniarek znajdował się również dom opieki nad matką i dzieckiem, w którym pomoc mogły znaleźć kobiety ciężarne pracujące $w$ fabryce oraz żony robotników zatrudnionych w zakładzie ${ }^{48}$. Jak wskazywał Pruszyński, rozwój przemysłu w Mikaszowicach dawał możliwość na lepsze życie ludności zamieszkującej Polesie, ale i polepszył sytuację gospodarczą i społeczną omawianego terenu. Nie da się jednak ukryć, że mieszkańców tego regionu zatrudniano na najniższych stanowiskach w fabrykach oraz zakładach, które znajdowały się w zamieszkiwanym przez nich województwie ${ }^{49}$. Większość robotników rekrutowanych było z obszarów spoza Polesia. Należy również zauważyć, że na terenie województwa poleskiego przemysł fabryczny nie rozwinął się w taki sposób, aby wytwarzane produkty mogły być eksportowane. Powodem nieuprzemysłowienia Polesia był przede wszystkim brak dróg komunikacyjnych, które ułatwiłyby transport produktów. Autor opisując Polesie, zwraca szczególną uwagę na ludność zamieszkującą omawiane tereny — wędruje on przez kresy i rejestruje rzeczywistość życia społecznego. Początki rozwoju fabryk na Polesiu, w których ludność miała szansę znaleźć pracę, były zapowiedzią zmian, jakie mogły zajść na omawianym obszarze. Pruszyński przedstawił tu wizerunek niezagospodarowanego, pomijanego przez władze II Rzeczypospolitej województwa poleskiego. Publikację Pruszyńskiego o Mikaszewiczach skrytykował Józef Mackiewicz, który zauważył, że pisarz skonstruował ów obraz, „niezbyt skrupulatnie wnikając za kulisy tych wielkich zakładów, opierając swe spostrzeżenia na danych mu podsuniętych i wyciągając wnioski z wykresów trochę tendencyjnych, a domków i kooperatyw wcale nie ideowych"50. Opis jest wyolbrzymiony, daleki od rzeczywistości. Pokazuje to, z jaką krytyką Mackiewicz podchodził do innych publicystów wypowiadających się na temat województwa poleskiego.

Kwestią, którą dostrzega oraz porusza w swoich reportażach Mackiewicz, jest natomiast problem ciężkiej sytuacji społecznej oraz ekonomicznej mieszkańców omawianego województwa. Publicysta nie bał się pokazać, jak bardzo

\footnotetext{
${ }^{47}$ K. Pruszyński, Kiełkowanie na bagnie...

48 Ibidem.

49 M. Marczak, op. cit., s. 46.

50 J. Mackiewicz, Okna zatkane szmatami..., s. 252.
}

Wrocławskie Studia Wschodnie 23, 2019

(C) for this edition by CNS 
„retuszowano” wygląd Polesia. W reportażu Taka sobie broszurka... opisał krótką publikację, w której znajdują się informacje dotyczące historii Polesia. Informacje w broszurze, co szybko zauważył Mackiewicz, mijały się z prawdą. Zdaniem dziennikarza Polesie traktowane było po macoszemu przez władze II Rzeczypospolitej, a po przyłączeniu Polesia do II RP i wyciągnięciu go spod władzy rosyjskiej pod względem gospodarczym oraz społecznym niewiele tu zmieniło się. Zdaniem Mackiewicza administracja nie dawała województwu poleskiemu nic prócz placówek Korpusu Ochrony Pogranicza ${ }^{51}$. Krytyczne opinie autora o władzy oraz sytuacji ekonomicznej na Polesiu należy uznać za wiarygodne w związku z jego dogłębną znajomością opisywanego przezeń terenu.

Mackiewicz zauważa również, że gospodarka Polesia to w głównej mierze utrzymywanie się ludzi ze sprzedaży drzewa, zbieranie trawy z bagien oraz łowienie ryb ${ }^{52}$. Trawa była pokarmem dla bydła, natomiast ryby i drzewo sprzedawano. Łowieniem ryb zajmowały się przede wszystkim osoby najuboższe. Z reportaży Mackiewicza wyłania się obraz Polesia nierozwiniętego, biednego, do którego nie dociera pomoc ze strony państwa ${ }^{53}$.

Należy w związku z tym raz jeszcze podkreślić, że ludność województwa poleskiego borykała się z licznymi problemami związanymi z kwestami gospodarczymi. Specyfika krajobrazu Polesia zmuszała ludzi do gospodarowania oraz wykorzystania szczególnie niegościnnych obszarów, które najczęściej były nieurodzajne ${ }^{54}$. Utrzymywano się głównie z uprawy roli, produktów, które można było uprawiać bądź też tworzyć na terenie regionu. Mimo prób podejmowanych przez władzę gospodarka w województwie poleskim nie poprawiła się w zadowalający sposób.

\section{Zakończenie}

Polesie było obszarem szczególnie niedostępnym. Omawiany teren to w głównej mierze bagna, lasy, łąki, miejsca sprzyjające rybołówstwu, myślistwu czy też ciekawe dla miłośników ornitologii. Charakterystyczne dla regionu zbieractwo, rybołówstwo oraz myślistwo były jednymi z nielicznych czynności, jakimi mogli zajmować się tutejsi mieszkańcy. Mimo działania władz, mającego na celu poprawę sytuacji gospodarczej województwa, nie udało się to między innymi z powodu trudnej sytuacji ekonomicznej Polski. Dzięki wspomnianym czynnościom mieszkańcy Polesia przygotowani do trudnych warun-

51 J. Mackiewicz, Bunt rojstów..., s. 145.

52 Ibidem, s. 127-128.

53 Ibidem.

54 P. Cichoracki, „Palâšuk”..., s. 80.

Wrocławskie Studia Wschodnie 23, 2019

(C) for this edition by CNS 
ków byli w stanie przeżyć szczególnie ekstremalne sytuacje, takie jak: odcięcie przez wodę wiosek od świata, zalanie miejscowości czy mroźne zimy. Polesie to obszar do teraz nieodkryty, pełen tajemnic, bezdroży i zapomnianych jezior. To miejsce, gdzie ludzie mogli znaleźć spokój i wytchnienie, jednak rzadko korzystało się z tej możliwości, co było spowodowane między innymi trudnymi warunkami komunikacyjnymi w województwie.

W tym miejscu należy zaznaczyć, że Polesie to nie tylko dziewicza natura pełna lasów oraz łąk, województwo poleskie czasu międzywojnia to również teren ze złożoną sytuacją narodowościową oraz gospodarczą, to różnorodność społeczeństwa. To wręcz tygiel narodowości, w którym znaczącą rolę odgrywają „tutejsi”, których pochodzenie trudno określić. Polesie to w dodatku społeczność żydowska, z którą próbowano żyć w zgodzie, oraz specyficzna struktura społeczna, której opis stanowił wyzwanie dla dziennikarzy i podróżników. Polesie to również ludność różniąca się od siebie pod względem wyznaniowym oraz kulturowym. To obszar z wieloma problemami, który nie był traktowany z należytą uwagą przez władze II Rzeczypospolitej. Problemy omawianego terenu były jednak dostrzegane przez dziennikarzy i reportażystów. Wyjątkowo trudnym zadaniem było zwrócenie uwagi na omawiany teren do tego stopnia, by opinia publiczna oraz władza poczyniły daleko idące kroki w celu poprawienia sytuacji życiowej ludności zamieszkującej to województwo. Każdy pisarz czy dziennikarz dostrzegał problemy związane $\mathrm{z}$ warunkami bytowymi na omawianym obszarze - ukazane zostały trudne warunki, które są bezpośrednio związane $\mathrm{z}$ brakiem wsparcia finansowego ze strony rządu dla województwa poleskiego.

Ossendowski, Pruszyński, Mackiewicz, Tołpa oraz Wasilewska w swoich reportażach tworzą fascynujący, zagadkowy wizerunek województwa poleskiego okresu dwudziestolecia międzywojennego. Porównując jednak wszystkie publikacje, należy stwierdzić, że jedynie w wypadku tekstów Mackiewicza dostrzega się pewną spójność w konstrukcji reportaży i składających się na nie opisów. Inne teksty są albo pojedynczymi reportażami bądź też nie tworzą całości, która ukazuje spójny opis województwa.

\section{Полесское воеводство в репортажах межвоенного двадцатилетия в Польше - избранные аспекты}

\section{Резюме}

Темой этого текста является вопрос о Полесском воеводстве в репортажах межвоенного двадцатилетия в Польше. В статье проанализированы и обсуждены публикации этого периода, в которых особое внимание обращено на ландшафт, социальную, госу- 
дарственную и экономическую ситуации Полесского воеводства в указанное время. Территория Полесья - это в основном болота, леса и луга, на которых, прежде всего, культивировалось сельское хозяйство. Это территория, которую характеризует трудная экономическая и социально-бытовая ситуация.

\title{
The Polesie Province in interwar reportage in Poland - selected aspects
}

\begin{abstract}
Summary
The article deals with the question of the Polesie Province as emerging from interwar reportage in Poland. The author analyses selected publications from the period, publications in which particular attention was paid to the landscape, social situation and economic situation of the Polesie Province in the period in question. Covered mainly by marshes, forests and meadows, Polesie was primarily an agricultural region, a place characterised by a difficult economic and social situation. The government of the Second Polish Republic made great efforts to improve the living conditions in the analysed region.
\end{abstract}

